Keywords:

Growth and yield average reference $\mathrm{DBH}$ guide curve methodology

Histórico:

Recebido 29/07/2016 Aceito 13/09/2016

Palavras chave: Crescimento e produção DAP médio de referência Metodologia da curva guia

Correspondência: hattisbeltran@gmail.com
Hernan Attis Beltran', Luis Chauchard', Abel Velásquez', Renato Sbrancia', Guillermo Martínez Pastur'

\section{DIAMETRIC SITE INDEX: AN ALTERNATIVE METHOD TO ESTIMATE SITE QUALITY IN Nothofagus obliqua AND N. alpina FORESTS}

ABSTRAT: The first step for constructing models of tree growth and yield is site quality assessment. To estimate this attribute, several methodologies are available in which site index $(\mathrm{SI})$ is a standard one. However, this approach, that uses height at a reference age of trees, can be simplified if age is replaced by another reference variable easier to measure. In this case, the diametric site index (DSI) represents the mean height of dominant trees at a reference mean diameter at breast height. The aim of this work was to develop DSI in pure and mixed Nothofagus alpina and $\mathrm{N}$. obliqua forests, and compare these models with the classical proposals based on height-age variables, within the temperate forest of northwestern Patagonia from Argentina, South America. Data originated from temporary plots and stem analyses were used. Tree age and diameter at breast height were obtained from each plot and used for establishing DSI family functions, following the guide-curve methodology. Site classes were proportionally represented among DSI curves of 17.0, $21.5,26.0,30.5$ and $35.0 \mathrm{~m}$ of dominant tree height. Reference diameter instead of reference age can be cautiously used in order to fit site index models.

\section{ÍNDICE DE SÍTIO DIAMÉTRICO: UM MÉTODO ALTERNATIVO PARA ESTIMAR A QUALIDADE DO SÍTIO EM FLORESTAS DE Nothofagus obliqua E N. alpina}

RESUMO: primeiro passo para a construção de modelos de crescimento e produção de árvores e a avaliação da qualidade do sítio. Para estimar este atributo, várias metodologias estão disponíveis, na qual o índice de sítio (IS) é padrão. No entanto, esta abordagem, que utiliza uma altura na idade de referência, pode ser simplificada se a idade é substituída por outra variável de referência mais fácil de medir. Neste caso, o índice de índice de sítio diamétrico (ISD) representa a altura média das árvores dominantes de um diâmetro à altura do peito referência. $\mathrm{O}$ objetivo deste trabalho foi desenvolver ISD para florestas puras e mistas de Nothofagus alpina e N. obliqua, e comparar esses modelos com as propostas clássicas baseadas nas variáveis altura-idade, para a floresta temperada do noroeste da Patagônia da Argentina, América do Sul. Dados provenientes de parcelas temporárias e análises de tronco foram utilizados. Foram obtidos idade e diâmetro à altura do peito de cada parcela e utilizados para o estabelecimento das funções da família DSI, seguindo a metodologia da curva-guia. Classes de sítio foram proporcionalmente representados entre curvas DSI de 17,0; 21,$5 ; 26,0 ; 30,5$ e 35,0 m de altura da árvore dominante. $O$ diâmetro de referência em vez da idade de referência pode ser usado com cautela para ajustar modelos de índice de sítio. 


\section{INTRODUCTION}

Forest stand productivity is largely defined as site quality which expresses the growth potential of the species, and it is influenced mainly by forest soils (SKOVSGAARD and VANCLAY, 2008; AVERY and BURKHART, 20I5). It is not possible to make reliable decisions without silvicultural references, as site quality and other stand conditions and variables which directly influences tree growth (DANIEL et al., 1982). For this, the study of site quality is the first necessary step for the construction of growth and yield models (ARIAS-RODIL et al., 20I5), which are essential in forest management and planning to determine the productive goals (RETSLAFF et al., 2015).

Biometric variables that influence tree growth are innumerable, thus forest models must be abstractions of reality (HARI, 1996) to simplify the complexity of the system for the modeling purposes and the subsequent practical uses (GARCÍA, I988; BLANCO et al., 20I5). Different methodologies exist to determine site quality according to employed biometric variables, and one of the most used methods for regular stands are based on indirect parameters using the average dominant height of the stand (BINOTI et al., 20I2). Dominant height $\left(h_{d o m}\right)$ growth is considered one of the best indicators, it is possible to relate it with the productivity of each site (MONSERUD, 1984), and in addition be correlated with growth in volume (DONOSO, 198I) with scarce influence of tree density within a wide range of conditions (DANIEL et al., I982; AVERY and BURKHART, 20I5).

However, in uneven-aged stands, the use of the dominant tree height as an indicator of site quality is complicated by the structural variability of the stands. In these stands, trees have periods of oppression and liberation at younger ages, impossible to determine in individual trees at mature ages, generating irregular or polymorphs growth patterns along the years. Also, there is difficulty to identifying tree ages at field, a costly task (ARIAS-RODIL et al., 20I5), making it advisable to try other options than the classic growth equation proposals (ZEIDE, I993; ARIAS-RODIL et al., 20I5). The use of classical site index ( $\mathrm{SI}$ ) methods requires the measuring of $h_{\text {dom }}$ at a reference age, and this can be facilitated if age can be replaced with another reference variable. If we consider other volume increase components, the diameter at breast height $(\mathrm{DBH})$ is the second variable in importance. The growth pattern of this variable was considered as more sensible than $\mathrm{h}_{\text {dom }}$ growth to changes in environmental factors (CORNELIUS, 1994), such as tree density.
However, it is possible to propose the hypothesis that within the lifespan of trees under natural dynamics in uneven-aged stands, the DBH growth of dominant trees are not strongly affected, then it can be proposed the use the $\mathrm{H}-\mathrm{DBH}$ instead $\mathrm{h}_{\text {dom }}$-age variables (BAKUZIS, 1969; HUANG; TITUS, 1993). Thus, site index can be defined as the average height of dominant trees with an average reference $\mathrm{DBH}$, rather than employing tree age, resulting in a diametric site index (DSI) that expresses the potential productivity of a stand, just as the classic proposal of SI.

Several authors propose different models for Nothofagus forests in Patagonia region of Argentina and Chile, always using SI based on $h_{\text {dom }}$-age variables. Polymorphic models were proposed for $N$. pumilio (Poepp. et Endl.) Krasser (MARTÍNEZ PASTUR et al., 1997), N. antarctica (Forster F.) Oersted (LENCINAS et al., 2002; IVANCICH et al., 20I I) and N. dombeyi (Mirb.) Oerst (ESSE et al., 2007; 20I4) to estimate SI, and many of them were incorporated into different biometric models (e.g. MARTÍNEZ PASTUR et al., 2002; 2008; ATTIS BELTRÁN et al., 20I3; IVANCICH et al., 20I4). Other studies developed anamorphic models for $N$. alpina Poepp. et Endl. = N. nervosa Phill (Dim. et Mil.) (raulí) and N. obliqua (Mirb.) Oerst, and proposed a mixed model for both species based on the similarity of their growth patterns (ATTIS BELTRÁN et al., 20I5). All these studies highlight the inconvenience of age estimation in the field, where some of them propose to estimate this variable using the tree bark as indicator of the growth stage or age class (e.g. MARTÍNEZ PASTUR, 2006; IVANCICH, 20I3). However, the use of DBH instead of bark can be a valid alternative for more accurate and practical uses in the forest management and planning. For this, the aim of this work was to develop DSI in pure and mixed, Nothofagus alpina and N. obliqua forests, and compare these models with the classical proposals based on $\mathrm{h}_{\mathrm{dom}}$ age variables developed by Attis Beltrán et al. (20I5).

\section{METHODS}

\section{Study area}

The natural area of distribution of Nothofagus obliqua is located between $33.0^{\circ}$ and $41.5^{\circ} \mathrm{SL}$, while $N$. alpina covers a slightly narrower latitudinal range between $35.0^{\circ}$ and $40.5^{\circ} \mathrm{SL}$ (DONOSO et al., 1993; SALAS; GARCÍA, 2006). The sampling was performed within the watershed of Lácar and Nonthué lakes (40 07 'SL and $71^{\circ} 27^{\prime} \mathrm{WL}$ to $40^{\circ} 07^{\prime} \mathrm{SL}$ and 7/ $39^{\circ} \mathrm{WL}$ ) covering an area of I,500 ha, where forest management 
of the National Reserve of Lanin National Park was conducted (Neuquén Province, Argentina). The forests were dominated by pure or mixed Nothofagus forest types located between 600 and I, 100 m.a.s.l. (CHAUCHARD; SBRANCIA, 2003). Climate is humid with annual temperatures of $9^{\circ} \mathrm{C}$ and rainfall close to I,800 mm.year ${ }^{-1}$. The region was shaped by glaciers and later during the Holocene covered by volcanic ash (MERCER, 1976), generating the dominant soils belonging to Andisol order. Soils presented a sequence of O-A-Bw-C horizons or sequences of these horizons due to successive ash deposits which resulted in buried soils (FERRER et al., 1991; FRUGONI et al., 2005).

\section{Data taking}

Samples were taken from pure and/or mixed even-aged mature ( $>150$ years old) $N$. alpina and $N$. obliqua stands, with complete overstory cover (>90\% without recent human intervention and without presence of large gaps) and with one dominant stratum (a stratum of upper crown and uniform with a normal and narrow diameter distribution). Two samplings were conducted:

(I) Data from temporary plots: We selected stands $(n=60)$ covering the dominant height $(10$ to $40 \mathrm{~m})$ and rainfall $\left(1,500\right.$ to 2,500 mm.year $\left.^{-1}\right)$ gradients in the study area. We established plots of $500 \mathrm{~m}^{2}$, measuring the $\mathrm{DBH}, \mathrm{H}$, species and social stratum of each tree. The plots should have a dominant tree generation. In each plot, we measured one to five dominant trees, which represent 20 to 100 dominant trees per hectare. We use these trees to evaluate the dominant height variation, increasing the number of trees if the variation was greater than $\pm 1.5 \mathrm{~m}$.

(2) Data from stem analysis: A total of 17 individuals of $\mathrm{N}$. alpina and $2 \mathrm{I}$ of $\mathrm{N}$. obliqua were cut for destructive sampling. Prior to cuts, dominance of each tree was evaluated by the relative size of indicative variables comparing them with the neighbor trees. The following indicative variables were used: (i) $\mathrm{H}$ with laser hypsometer (VL5360 model, Haglöf, Sweden), (ii) $\mathrm{DBH}$ (average of two measurements at $90^{\circ}$ ) with forest caliper, and (iii) crown characteristics, where individual crown must be balanced in size and shape, and lateral growth must represent $25-40 \%$ of $\mathrm{H}$ as an indicator of competition with the neighbor trees. Trees with greater values and lateral branch presence were consider as free growth trees and were avoided from the sampling. Only trees originated by seed were selected for the samplings, avoiding coppice strain trees, identified as individuals with great buttresses at the base of the trunk.
Wood slices were extracted from the harvested trees at $0.30 \mathrm{~m}, 1.30 \mathrm{~m}, 3.30 \mathrm{~m}$, and every $3.00 \mathrm{~m}$ to the tree apex following the main stem. Northern aspect of each slice was identified for the measurements at laboratory. Prior to counting and measurement of growth treerings, we proceeded to sanding the slices, starting with coarse-grained $(80)$ and gradually reach to fine-grained (360) sandpapers. With ages and diameters at different heights, we built tree profiles for five-year periods. For the last period of growth, at the apex area, profiles were completed by the graphical method, following the profile trend (CHAUCHARD, 200I).

\section{Modelling}

First, a graph of average dominant DBH (obtained from 55 permanent plots) based on the stand density index (SDI) (CHAUCHARD et al., 1999) was made to assess the impact of stand density in each species diameters. And then, we examined the number of trees that can be measured per plot to obtain reliable field-work data. The differences between dominant height of 100 trees per hectare ( 5 per plot of $500 \mathrm{~m}^{2}$ ), dominant height of 80 trees per hectare (4 per plot of $500 \mathrm{~m}^{2}$ ), dominant height of 60 trees per hectare (3 per plot of $500 \mathrm{~m}^{2}$ ), dominant height of 40 trees per hectare (2 per plot of $\left.500 \mathrm{~m}^{2}\right)$, and dominant height of 20 trees per hectare ( 1 per plot of $500 \mathrm{~m}^{2}$ ), were examined in a graphic of dominant height vs. number of trees per plot.

Data pairs of $h_{\text {dom }}-D B H$ were obtained from each plot (sampling I) and from tree profiles (sampling 2), and were used for setting the family of DSI functions. For construction of a family of dominant height curves based on the average $\mathrm{DBH}$, we proceeded according to the guide curve methodology (CLUTTER et al., 1983; BINOTI et al., 2012; RETSLAFF et al., 2015). For this purpose, the nonlinear function usually known as Chapman-Richards was used [I], which belongs to the so called biological functions, for their demonstrated flexibility for studies related to growth phenomenon (RICHARDS, 1959; OSUMI, 1983; VANCLAY, 1994; MARTÍNEZ PASTUR et al., 1997; CHAUCHARD, 200I; CARRERO et al., 2008; IVANCICH et al., 20I I; ATTIS BELTRÁN et al., 20I5; DO AMARAL MACHADO et al., 20I5; OLIVEIRA et al., 20I5). Where $h_{\text {dom }}$ : dominant height; a: parameter related to the asymptote of the function; $b$ : parameter related to the rate of change; c: parameter linked to the inflection point; Da: average $\mathrm{DBH}$.

$\mathrm{h}_{\mathrm{dom}}=\mathrm{a}(1-\exp (\mathrm{b} \cdot \mathrm{Da}))$ 


$$
D S I=a(1-\exp (b . D r))^{c}
$$

With the database, we defined two data groups, one for $\mathrm{N}$. alpina and another for N. obliqua, and Equation I was fitted to the data pairs of each species $\left(h_{\text {dom }}-D B H\right)$, constituting two guide curves.

In the present proposal, the DBH will be the reference, so $h_{\text {dom }}$ of Equation I will be replaced by the diametric site index (DSI) (Equation 2), therefore: where DSI: diametric site index; Dr: reference average $\mathrm{DBH}$; a, $\mathrm{b}$ and $\mathrm{c}$ : parameters.

For the generation of the family proportional curves or anamorphic curves, we applied a mathematical conversion between Equations (I) and (2) to obtain an invariant single equation between (Equation 3) the dominant height and DSI (Equation 4).

$$
\begin{aligned}
& \frac{H_{\text {dom }}}{\text { DSI }}=\frac{a(1-\exp (- \text { b. Da }))^{c}}{a(1-\exp (- \text { b. Dr }))^{c}} \\
& \text { Solving for DSI as, } \\
& D S I=\frac{H_{\text {dom }}}{(1-\exp (- \text { b. Da }))^{c}} \cdot(1-\exp (- \text { b. Dr }))^{c}
\end{aligned}
$$

To evaluate the goodness of fit we used: (i) standard error of the estimation (SEE), (ii) mean absolute error (MAE), (iii) residual distribution, and (iv) graphical goodness of the guide curve which represent the trend of the point cloud and the biological significance of the parameters.

With the outputs of Equation (4) it is possible to define site quality classes based on DSI constant ranges. We compare the models of each tree species, analyzing the goodness of fit parameters and graphical behaviors. This allowed us to analyze the chance to develop a single model for both species. We established the DSI and $\mathrm{SI}$ as proposed by Attis Beltrán et al. (2015) for trees that we performed stem analysis, and compared the correspondence to classify the site class of each dominant tree. Equations were fitted to explain the variation of the DSI as a function of SI, which they were evaluated by the coefficient of determination $\left(r^{2}\right)$, SEE and MAE. Finally, the behavior of the variable $\mathrm{SI}$ was studied as a function of fixed diameters $(20,25,30$ and $35 \mathrm{~cm})$ and age according to stem analysis data.

\section{RESULTS}

\section{Data base characterization}

A constant trend of $\mathrm{Da}$ (Average $\mathrm{DBH}$ ) through different stand densities (using SDI index) was found
(Figure I), which was obtained using the criteria of the proposed methodology.

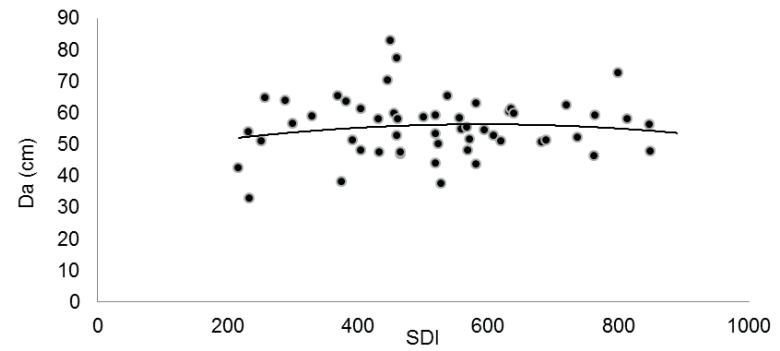

FIGURE I Relations between average DBH (Da) and Stand density index (SDI).

We defined that 3 trees can be measured per plot to obtain reliable field-work data. Average $h_{\text {dom }}$ slightly decrease when increasing the number of dominant trees for each plot, however, the decrease in the average between three and five dominant trees was considered acceptable, in the range of $\pm 3.5 \%$ (Figure 2). In order to have a consistent average $h_{\text {dom }}$ and DBH values, dominant trees of the same cohort or same age class must be selected, and the closer the measured trees are to mature phases, the more reliable will be the site class estimation. The differences between dominant height of 100 trees per hectare ( 5 per plots of $500 \mathrm{ha}$ ) and dominant height of 60 trees per hectare ( 3 plots of 500 ha) are within the range mentioned (Table I).

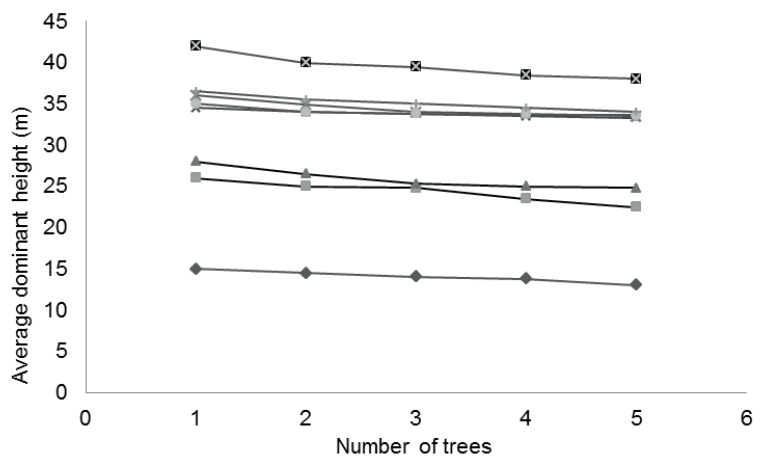

FIGURE 2 Changes in the dominant height value according to the number of measured trees considered in each temporary plot.

TABLE I Comparison between the average of 100 and 60 dominant heights per hectare (hdom), and the absolute differences, resulting in an average underestimation of $3.5 \%$.

\begin{tabular}{ccc}
\hline $\begin{array}{c}\text { hdom 60 } \\
{[\mathrm{m}]}\end{array}$ & $\begin{array}{c}\text { hdom I00 } \\
{[\mathrm{m}]}\end{array}$ & $\begin{array}{c}\text { Difference } \\
{[\mathrm{m}]}\end{array}$ \\
\hline 15.0 & 14.5 & 0.5 \\
20.0 & 19.3 & 0.7 \\
25.0 & 24.1 & 0.9 \\
30.0 & 29.0 & 1.1 \\
35.0 & 33.8 & 1.2 \\
40.0 & 38.6 & 1.4 \\
\hline
\end{tabular}


The plots database was composed of $237 \mathrm{~h}_{\text {dom }}$ DBH points of both species ( $N$. alpine 90; $N$. obliqua 147). The average DBH of $N$. alpina was $48.2 \mathrm{~cm}$ (min: $9.5 \mathrm{~cm}$; $\max 129.0 \mathrm{~cm}$ ), and the average $\mathrm{DBH}$ of $\mathrm{N}$. obliqua was $52.5 \mathrm{~cm}$ (min: $8.7 \mathrm{~cm}$; $\max 162.0 \mathrm{~cm}$ ). The average $h_{\text {dom }}$ of $N$. alpina was $24.1 \mathrm{~cm}$ (min: $8.3 \mathrm{~cm}$; max $41.0 \mathrm{~cm}$ ), and the average $h_{\text {dom }}$ of $N$. obliqua was $25.4 \mathrm{~cm}$ (min: $8.4 \mathrm{~cm}$; $\max 44.5 \mathrm{~cm}$ ). These data present a similar distribution in a two-dimensional graph (Figure 3a). Stem analysis database was composed of $|3|$ height-DBH points of $17 \mathrm{~N}$. alpina (62 data points) and $21 \mathrm{~N}$. obliqua (69 data points). The average $h_{\text {dom }}$ of $N$. alpina was $17.6 \mathrm{~cm}$ (min: $13.0 \mathrm{~cm}$; $\max 23.7 \mathrm{~cm}$ ), and the average $h_{\text {dom }}$ of $N$. obliqua was $18.8 \mathrm{~cm}$ ( $\min : 10.7 \mathrm{~cm} ; \max 30.2 \mathrm{~cm}$ ). The average age of $N$. alpina was 58.5 years (min: 39 years; max 87 years), and the average age of $N$. obliqua was 62.7 years ( $\mathrm{min}: 37$ years; max 115 years) (Figure $3 b$ ). The data of the stem analyses allowed to incorporate not only $h_{\text {dom }}-D B H$ data pairs, but also allowed to incorporate $h_{\text {dom }}$-age data pairs. The data for each tree were defined for different $\mathrm{DBH}$ baseline: $20,25,30$ and $35 \mathrm{~cm} \mathrm{DBH}$, and also to obtain $\mathrm{h}_{\mathrm{dom}}$-age when dominant trees had these $\mathrm{DBH}$.
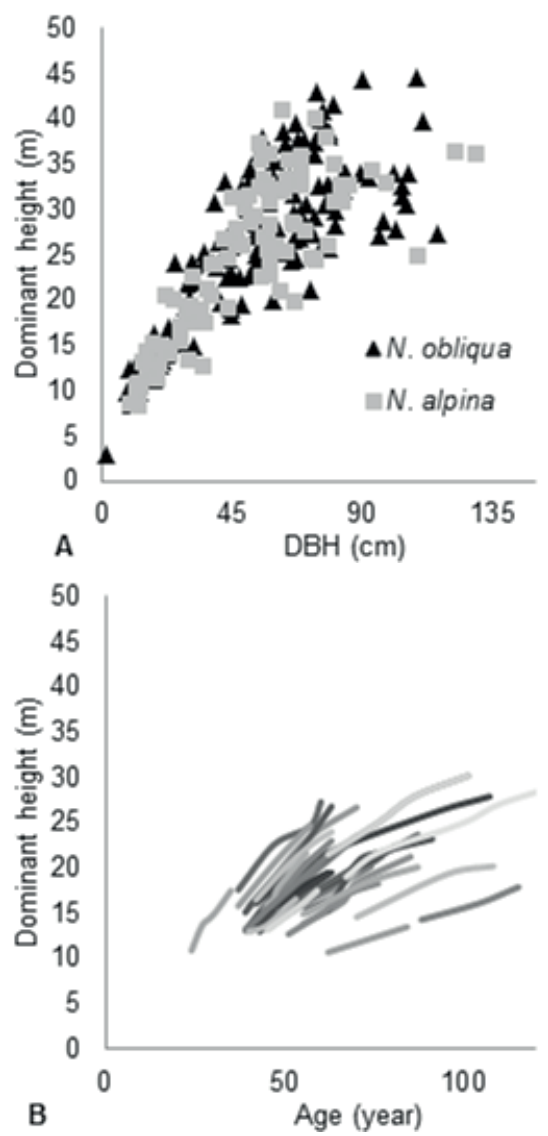

FIGURE 3 A: Representation of hdomH-DBH pair plots obtained from temporary plots. B: Representation of the hdomH-age data obtained from stem analysis. Both graphs includeds the two studied species: Nothofagus obliqua and N. alpina.

\section{Evaluation and performance of the fitted models}

The three models obtained with the ChapmanRichards equation (N. alpina, $N$. obliqua and mixed) presented acceptable and comparable metrics (Table 2) with no evident differences among the estimated parameters. Graphical representation of the three models denotes good biological behavior, being very similar between species and this behavior was well represented in the mixed species model (Figure 4). In the residual analyses, similar trends among the three models were observed (Figure 5).

According to the obtained results, we decided to employee the model of both species (mixed model), which allowed the use of one equation for both species (N. obliqua and $N$. alpina), simplifying application for managers and decision makers.

TABLE 2 Parameters ( $a, b$ and $c$ ) and adjustment goodness of fit metrics for the three models: coefficient of determination $\left(r^{2}\right)$, standard error of estimation (SEE) and mean absolute error (MAE).

\begin{tabular}{ccccccc}
\hline Model & $\mathrm{a}$ & $\mathrm{b}$ & $\mathrm{c}$ & $\mathrm{r}^{2}(\%)$ & SEE & MAE \\
\hline N. alpina & 39.17 & 0.02730 & $\mathrm{I} .200$ & 73.71 & 4.04 & 3.16 \\
N. obliqua & 38.03 & 0.03060 & 1.280 & 68.88 & 4.50 & 3.79 \\
mixed & 39.28 & 0.02710 & $\mathrm{I} .190$ & 70.99 & 4.21 & 3.49 \\
\hline
\end{tabular}

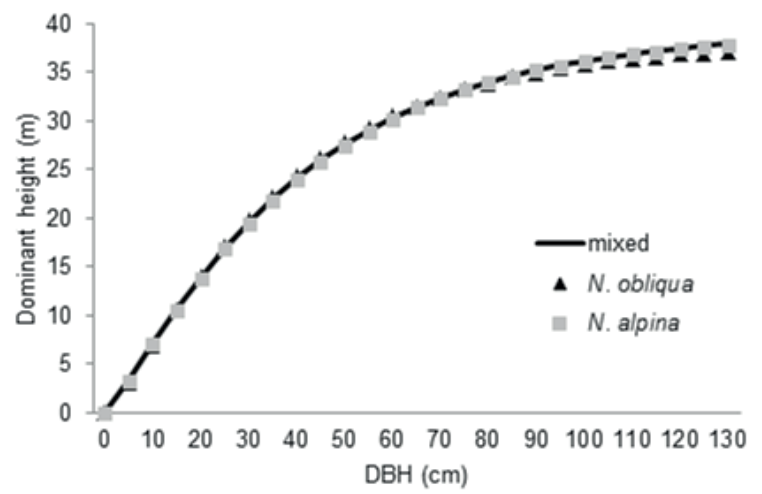

FIGURE 4 Chapman-Richards models fitted for Nothofagus alpina, N. obliqua and for both species (mixed model).

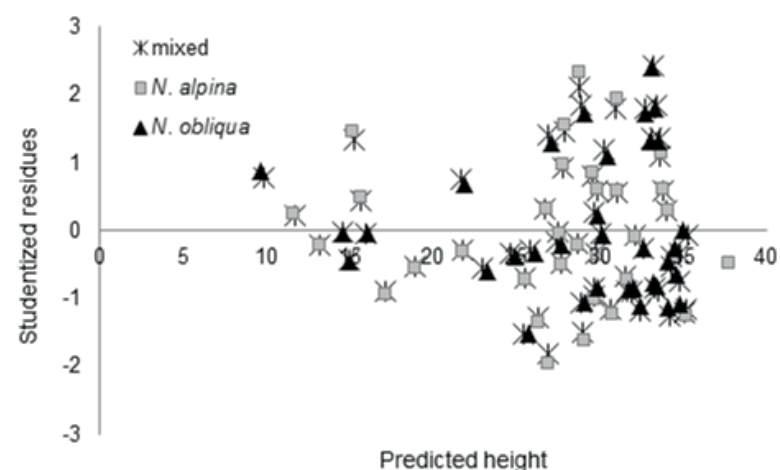

FIGURE 5 Residuals of the adjusted fitted models: Nothofagus alpina, N. obliqua and for both species (mixed model). 
As reference diameter, $\mathrm{Da} 45 \mathrm{~cm}$ was chosen, compatible with the development phase and the average diameter expected for the rotation term of the proposed management (CHAUCHARD et al., 20I2). For this, when Da reached $45 \mathrm{~cm}$, the dominant height in function [6] represent the DSI. Where: DSI: diametric site index.

$\mathrm{DSI}=39.28(1-\exp (-0.02711 \cdot 45))^{1.187}$

After that, we obtain the ratio between expressions [5] and [6]:

$\frac{\mathrm{H}_{\text {dom }}}{\mathrm{DSI}}=\frac{39.28(1-\exp (-0.02711 \cdot \mathrm{Da}))^{1.187}}{39.28(1-\exp (-0.02711 \cdot 45))^{1.187}}$

And the resolution of this ratio can be expressed as equation [7]:

$\mathrm{DSI}=\frac{\mathrm{H}}{(1-\exp (-0.02711 \cdot \mathrm{Da}))^{1.187}}(1-\exp (-0.02711 \cdot 45))^{1.187}$

Based on the constant proportionality principle (PRODAN et al., 1997) and assigning the reference diameter $(45 \mathrm{~cm})$, average DSI was conceived at approximately 26 meters. Then, a $4.5 \mathrm{~m}$ range of heights was designated for the different site qualities. Thus, site classes will be represented proportionally between the DSI curves 17.0, 21.5, 26.0, 30.5 and $35.0 \mathrm{~m}$ of dominant height (Figure 6). The curves family obtained with the DSI model [7] data covering the entire range of class sites.

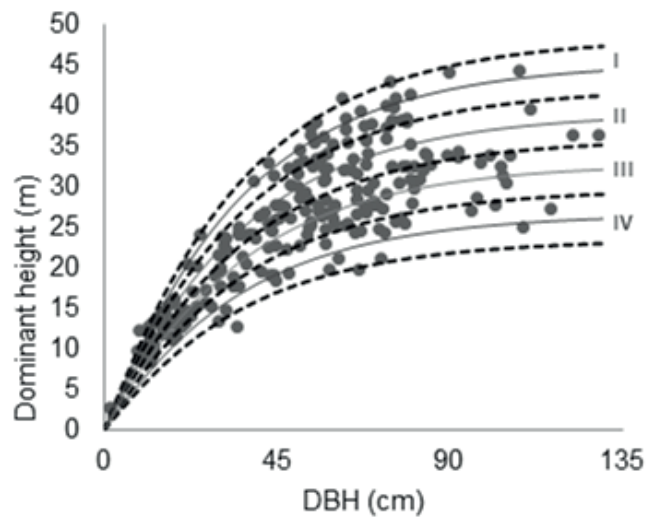

FIGURE 6 DSI family curves for the mixed model (Nothofagus alpina and $\mathrm{N}$. obliqua) and hdom-DBH data. The curves belong to the $17.0 \mathrm{~m}, 21.5 \mathrm{~m}, 26.0 \mathrm{~m}, 30.5$ $\mathrm{m}$ and $35.0 \mathrm{~m}$ DSI defining the different classes $(\mathrm{I}=$ $30.5-35.0 \mathrm{~m}, \mathrm{II}=26.0-30.5 \mathrm{~m}, \mathrm{III}=21.5-26.0 \mathrm{~m}$, $\mathrm{IV}=\mid 7.0-2 \mathrm{I} .5 \mathrm{~m})$.

\section{Comparisons and relationships between DSI and SI}

When data of stem analysis were classified according DSI and $\mathrm{SI}, 85 \%$ of them, matched $(\mathrm{n}=$
1 19) the proposed site classes. The remaining 15\% site classes determined by both methods were contiguous with the exception of two data pairs of $N$. obliqua. The fitted model [8] relate the DSI and SI, and indicated a significant relationship between the two indices (Figure 7). The obtained function has the following equation [8]:

$\mathrm{SI}=0.60 \cdot \mathrm{DSI}-0.52$

$r^{2}: 57.39 \%$, SEE: I.67, MAE: I.34 ( $p<0.000$ I)

We also found a clear relationship between the diameter of the dominant trees and $\mathrm{SI}$ and age variables (Figure 8). The trend between $\mathrm{SI}$ and age remains constant through the different diameter classes previously established $(20,25,30$ and $35 \mathrm{~cm})$, indicating that upper limit of diameter growth of dominant trees is related to height growth, so higher diameters will be found at higher site qualities.

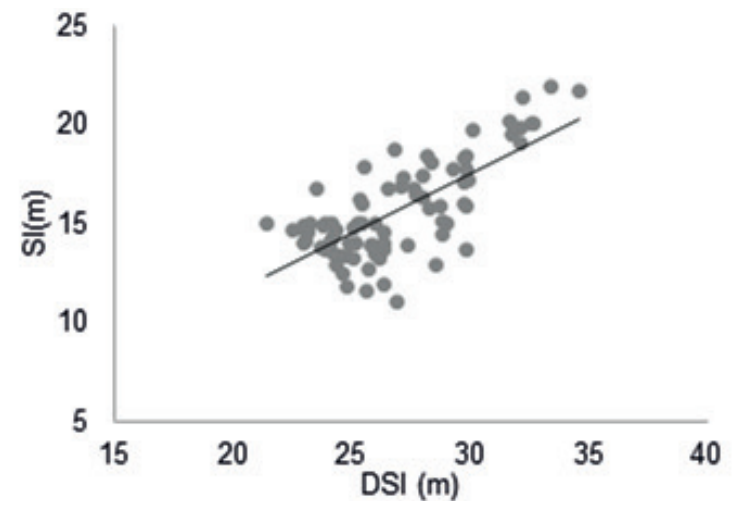

FIGURE 7 Relationship between DSI and SI.

\section{DISCUSSION}

Reference diameter was tested for use instead of the reference age in the construction of a site index model. A constant trend of $\mathrm{Da}$ (obtained according to the described methodology) through different densities (using SDI index) allowed to use the reference diameter to develop the DSI, supporting the hypothesis that diameter growth of dominant trees was not greatly affected (Figure I) in a wide range of densities in forests growing under a natural dynamic (BAKUZIS, 1969; HUANG; TITUS, 1993). We tested the number of trees needed to measure to determine the reference value of the stand, as the dominant height was used in the traditional models. The costs of forest inventories are directly related to the amount of data to be taken at field and the difficulty of the methodologies to obtain those variables (LENCINAS et al., 2002). Usually, site index is related to dominant height, and dominant height is defined as the average of 100 tallest trees per hectare. 
A
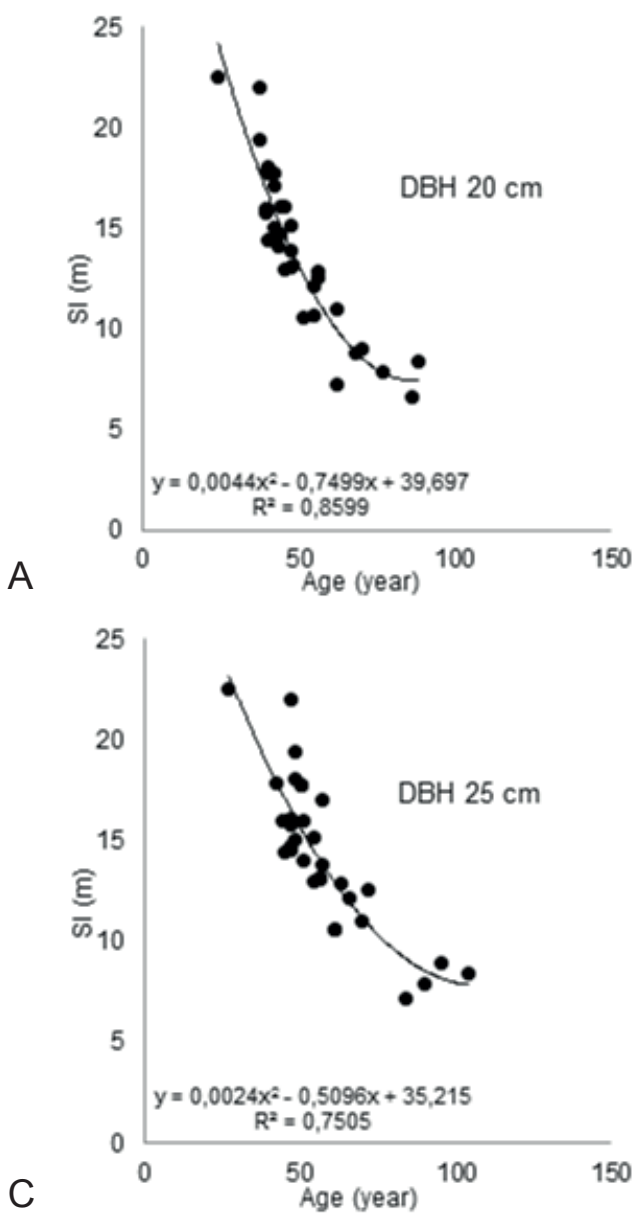
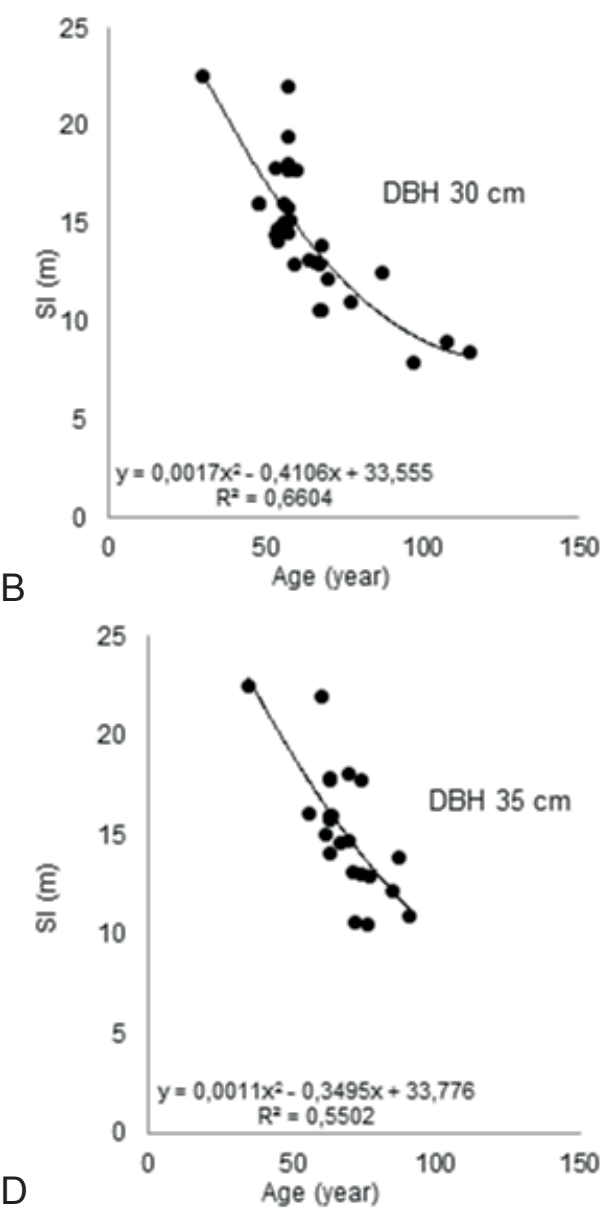

FIGURE 8 Relations between SI, DBH and age.

If we know how many trees below this number can be measured without significantly changing the final output, we can decrease the cost of dominant height estimation (Table I). The correct quantification of tree height is essential, especially used to calculate volume of timber stands and classify productivity (MOREIRA et al., 20I5). Beside this, if we can use the diameter instead the dominant height, we can further decrease the costs of estimating site quality using DSI.

Trees chosen for height and diameter indexes must belong to the dominant generation of the forest structure of the studied stand, which usually belong to mature phase (CHAUCHARD et al., 1999). Measurement in an overripe phase should be avoided, over-mature trees can significantly positively weigh on diameter relationships resulting in an underestimation of the site quality; also over-mature trees generally have reduced total height by breaking the apex or due to self-decay process of age. Although it is not common to find trees with large buttresses, indication of an asexual origin, in this study these trees were avoided because it is unknown if there are differences in growth patterns between trees originated by seed and agamic origins (HAWLEY; SMITH, 1972). The methodology employed here to determine the origin of trees, as differences or similarities in the growth pattern of natural trees, should be better studied and tested for future studies, including recent studies in tree architecture and growth-unit structure (e.g. PUNTIERI; GHIRARDI 20I0; PUNTIERI et al., 20I3).

A close similarity was observed between the outputs of our model fitted for each species and mixed species model, and those presented by Attis Beltran et al. (2015) in the fitting of SI curves for N. alpina and $N$. obliqua. The residual graph showed that estimation errors for each observation through the mixed species model compared to models of each species are randomly distributed, which indicated that there is not a marked overestimation or underestimation. Due to the mixed species model having showed good statistics and biological behavior for $N$. alpina and N. obliqua, as was cited before by Attis Beltran et al. (20I5), we decide to 
continue working with the mixed species model without considering the individual species models.

Usually, for models such as Chapman-Richards, the biological behavior is equally important to the goodness of fit metrics (IVANCICH et al., 20I I). Dominant height growth of $N$. alpina and $N$. obliqua above $70-80 \mathrm{~cm}$ of $\mathrm{DBH}$ should be very small, since at least $1 \%$ of the dominant generation can overcome the $\mathrm{DBH}$ of $80 \mathrm{~cm}$, so all height growth curves should have a plateau relative to this diameter (CHAUCHARD, 199I; CHAUCHARD; SBRANCIA, 2003). Although the statistical and biological setting is very good, the plateau of our function appear later than expected (DBH 90-100 cm), however an indicator of fitting was the estimation of parameter "a" which represents the asymptote function of the value. If we compare our model with those presented before, in the range of heights of these forests ( 15 to $50 \mathrm{~m}$ ), the average value of $36 \mathrm{~m}$ determines the logic behavior of the function (SALAS; GARCÍA, 2006; ATTIS BELTRÁN et al., 20I5). The differences among the site classes obtained through IS and DSI can be explained thorough the employed methodology in each case, and may be due to the fact that DSI classes were not obtained from the diameter averages and were obtained from the individual $\mathrm{DBH}$ of the stem tree analyses. In fact, this could affect those points that had not coincided in the site classifications.

The fitted model [8] (Figure 7) showed the correlation between the two developed indices, where DSI and SI presented a strong relationship. It is well known that $\mathrm{DBH}$ is more affected than $\mathrm{h}_{\text {dom }}$ by density (DANIEL et al., 1982). In these forests, diameter growth of dominant trees were not greatly affected by density, and suppressed trees mainly reduce their diameter growth due to competition or other biotic factors (e.g. diseases) (Attis Blentrán et al., 2013). This assumption about the growth of dominant trees support the use of the average reference diameter for these Nothofagus species, and must be tested for other forest types.

Relations among $\mathrm{SI}, \mathrm{DBH}$ and age were presented in Figure 8, which support the proposal of use of average reference diameter instead of a reference age. In this graph it is possible to see that trees growing in better SI achieve early the same reference $\mathrm{DBH}$, e.g. both small $(30 \mathrm{~cm})$ and large trees $(45 \mathrm{~cm})$ close to the reference diameter. Based on the mentioned relationships between $h_{\text {dom }}, D B H$ and age, Huang and Titus (1993) developed relations of $\mathrm{SI}$ using diameter-height ratios for Picea glauca (Moench) Voss, Pinus contorta Dougl., Populus tremuloides Michx. and Picea mariana (Mill.) B.S.P., and using the average indices for each species they obtained one index for the mixed forests. In our study, through the fitting of both species and the similar growth patterns between $N$. alpina and N. obliqua, a DSI for mixed forests was developed without mixing the average values of both pure forests.

Using the DSI (reference diameter) has remarkable advantages over the use of traditional SI (reference age) because age is a very expensive and highly difficult data to measure in natural forests. The disadvantage of DSI versus traditional $\mathrm{SI}$ is that the first method requires a proper choice of trees for measurements, with much subjectivity which can result in undesirable structural variability of field data. Beyond the advantages and disadvantages of the method, DSI consistently determines the relationship between average diameter and height of dominant trees along the site quality gradient.

DSI is a method designed to facilitate the work of managers, due to the fast site class classification of stands in the field. It is an indispensable management tool for future forest planning in the Lanin National Park. DSI methodology should be considered to categorize site quality of forest where age is difficult and costly to obtain, or for those forests which required an agile method of classification in the field (WATT et al., 2008). This tool, associated with satellite imagery and forest inventory tools, allows the generation of site quality maps and hence productivity, an indispensable tool for management and conservation plans (ESSE, 20I5).

\section{CONCLUSIONS}

It is possible to use a reference diameter instead of age reference to fit site index models, within certain limits and precautions that the method required. In this sense, a unique system of diametric site index curves for pure and mixed stands of $N$. alpina and $N$. obliqua was built. Thus, an average reference diameter was used instead of the reference age, commonly used in traditional indices to classify site quality. Using these models, we can define four site quality classes with a regular range among DSI curves: 17.0, $21.5,26.0,30.5$, and $35.0 \mathrm{~m}$.

\section{REFERENCES}

ARIAS-RODIL, M.; CRECENTE-CAMPO, F; BARRIOANTA, M.; DIÉGUEZ-ARANDA, U. Evaluation of age-independent methods of estimating site index and predicting height growth: a case study for maritime pine in Asturias (NW Spain). European Journal of Forest Research, 134(2), 223-233. 2015.

ATTIS BELTRÁN, H; MARTÍNEZ PASTUR, G.; IVANCICH, H.; LENCINAS, M.V.; CHAUCHARD, L. Tree health influences diameter growth along site quality, crown class and age gradients in Nothofagus forests of Southern Patagonia. Journal of Forest Science 59: 328-336. 2013. 
ATTIS BELTRÁN, H.; CHAUCHARD, L.M.; MARTÍNEZ PASTUR, G. Curvas preliminares de índice de sitio para bosques puros y mixtos de Nothofagus alpina y N. obliqua en la Patagonia Argentina. Bosque 36 (2): 275-285. 2015.

AVERY, T.E.; H.E. BURKHART. Forest measurements. Fifth Edition. Waveland Press Inc. New York, US. 2015.

BAKUZIS, E.V. Forestry viewed in an ecosystem perspective. In: Van Dyne, G.M. (Ed.), The ecosystem concept in natural resource management. Academic Press, New York: 189-258. 1969.

BINOTI, D.; DA SILVA BINOTI, M.; LEITE, H. Aplicação da função hiperbólica na construção de curvas de índice de local. Revista Árvore, 36(4), 74I-746. 2012.

BLANCO, J.A.; GONZÁLEZ DE ANDRÉS, E.; SAN EMETERIO, L.; LO, Y. Modelling mixed forest stands: methodological challenges and approaches. In: Advanced modelling techniques studying global changes in environmental sciences (Park, Y.S.; Lek, S.; Baehr, C.; Jorgensen, S.E.; Eds.). Developments in environmental modelling 27. Ed. Elsevier, Oxford, UK. Pp I89-2I6. 2015.

CARRERO, O.; JEREZ, M.; MACCHIAVELLI, R.; ORLANDONI, G.; STOCK , J. Ajuste de curvas de índice de sitio mediante modelos mixtos para plantaciones de Eucalyptus urophylla en Venezuela. Interciencia 33(4): 265-272. 2008.

CHAUCHARD, L.; BAVA, J.; CASTAÑEDA, S.; LACLAU, P.; LOGUERCIO, G.; PANTAENIUS, P.; RUSCH, V. Manual para las buenas prácticas forestales en bosques nativos de norpatagonia. Buenos Aires: Unidad para el Cambio Rural, Ministerio de Agricultura, Ganadería y Pesca. 122 pp. 2012.

CHAUCHARD, L.; SBRANCIA, R.; GONZÁLEZ PEÑALBA, M.; MARESCA, L.; RABINO, R. Aplicación de leyes fundamentales de la densidad a bosques de Nothofagus: I. Regla de los $-3 / 2$ o ley del autorraleo. Bosque 20(2): 7994. 1999.

CHAUCHARD, L.; SBRANCIA, R. Modelos de crecimiento diamétrico para Nothofagus obliqua. Bosque 24(3): 3-16. 2003.

CHAUCHARD, L. Modelos de crecimiento individual del raulí (Nothofagus alpina (Poepp. et Endl.) Oerst). Actas VI Jornadas Técnicas: Inventario, modelos de producción y crecimiento forestales. Eldorado, Misiones: 246-276. I991.

CHAUCHARD, L. Crecimiento y producción de repoblaciones de Pinus radiata $\mathrm{D}$. Don en el territorio histórico de Gipuzkoa (País Vasco). Servicio Central de Publicaciones del Gobierno Vasco. Departamento de Agricultura y Pesca No 40: I73 pp. 200I.

CLUTTER, J.; FORSTON, J.; PIENAAR, L.; BRISTER, G.; BAILEY, R. Timber Management: A quantitative approach. New York. John Wiley \& Sons. 333 pp. 1983.
CORNELIUS, J. The effectiveness of plus-tree selection for yield. Forest Ecology and Management 67: 23- 34. 1994.

DANIEL, P.; HELMS, U.; BAKER. F. Principios de Silvicultura. Ed. McGraw-Hill. 492 pp. 1982.

DO AMARAL MACHADO, S.; DE SOUZA, R.; APARECIDO, L.; RIBEIRO, A.; CZELUSNIAK, B. Evolução das variáveis dendrométricas da bracatinga por classe de sítio. Cerne, 2 I (2), 199-207. 2015.

DONOSO, C. Tipos Forestales de los Bosques Nativos de Chile. Investigación y Desarrollo Forestal, Documento de Trabajo N³8.69 pp. 198I.

DONOSO, C. Bosques templados de Chile y Argentina: variación, estructura y dinámica. Editorial Universitaria, Santiago, Chile. 455 pp. 1993.

ESSE, C.; NAVARRO, C.; PINARES, J. Curvas de índice de sitio para Nothofagus dombeyi en la zona preandina, provincia de Cautín, IX Región, Chile. Bosque 28(2): |42-I5I 2007.

ESSE, C.; DONOSO, P.; GERDING, V.; NAVARRO, C.; ENCINA-MONTOYA, F. Modelling dominant height and site index in different edaphoclimatic zones of Nothofagus dombeyi secondary forest in the Andes of south-central Chile. Southern Forests 3: I-8. 2014.

ESSE, C. Estimación del índice de sitio en rodales de Nothofagus dombeyi a través de herramientas de teledetección espacial. Sustainability, Agricultural, Food and Environmental Research 2(I): 53-63. 2015.

FERRER, J.; IRIZARRI, J.; MENDÍA, J. Estudio regional de suelos de la provincia de Neuquén. Consejo Nacional de Inversiones, Consejo de Planificación y Acción para el Desarrollo, Neuquén, Argentina. I59 pp. 1991.

FRUGONI, M.; RABINO, A.; CHAUCHARD, L. La distribución de los bosques de Nothofagus y su relación con los factores de sitio en una sub-cuenca de la Patagonia Andina. Acta del tercer Congreso Forestal Argentino y latinoamericano (ID 145): 89-90. 2005

GARCÍA, O. Growth modelling - A (re)view. New Zealand Forestry 33(3): 14-17. 1988.

HARI, P. Idealization and concretization in construction of models applied to forest growth. The Science of the Total Environment 183: 179-185. 1996.

HAWLEY, R.; SMITH, D. Silvicultura Práctica. 544 pp. 1972.

HUANG, S.; TITUS, S. An index of site productivity for unevenaged or mixed-species stands. Canadian Journal of Forest Research 23: 558-562. 1993.

IVANCICH, H.; MARTÍNEZ PASTUR, G.; PERI, P. Modelos forzados y no forzados para el cálculo del índice de sitio en bosques de Nothofagus antarctica en Patagonia Sur. Bosque 32(2): |35-|45. 20| |. 
IVANCICH, H. Relaciones entre la estructura forestal y el crecimiento del bosque de Nothofagus antarctica en gradientes de edad y calidad de sitio. Doctoral thesis. Universidad Nacional de La Plata, La Plata, Argentina. 2013.

IVANCICH, H; G MARTÍNEZ PASTUR; MV LENCINAS; JM CELLINI; PL PERI. Proposals for Nothofagus antarctica diameter growth estimation: Simple vs. global models. Journal of Forest Science 60(8): 307-3 I7. 2014.

LENCINAS. M.; MARTÍNEZ PASTUR, G.; CELLINI, J.; VUKASOVIK, C.; PERI, P.; FERNÁNDEZ, C. Incorporación de la altura dominante y la calidad de sitio a ecuaciones estándar de volumen para Nothofagus antarctica (Forster) Oersted. Bosque 23(2): 5-17. 2002.

MARTÍNEZ PASTUR, G.; PERI, P.; VUKASOVIC, R.; VACCAR, S.; PIRIZ CARRILLO, V. Site index equation for Nothofagus pumilio Patagonian forest. Phyton 6I (I/2): 55-60. 1997.

MARTÍNEZ PASTUR, G; LENCINAS, M.V.; CELLINI, J. M.; DIAZ, B; PERI, P.; VUKASOVIC, R. Herramientas disponibles para la construcción de un modelo de producción para la lenga (Nothofagus pumilio) bajo manejo en un gradiente de calidad de sitio. Bosque 23(2): 69-80. 2002.

MARTÍNEZ PASTUR, G. Biometría y producción forestal para bosques naturales de Nothofagus pumilio en Tierra del Fuego. Doctoral thesis. Universidad Nacional del Sur, Bahía Blanca, Argentina. 2006.

MARTÍNEZ PASTUR, G; CELLINI, J. M.; LENCINAS, M.V.; PERI, P. Stand growth model using volume increment/ basal area ratios. Journal of Forest Science 54(3): 102-108. 2008.

MERCER, J. Glacial history of southernmost South America. Quaternary Research 6: 125-166. 1976.

MONSERUD, R. Height growth and site index curves for inland Douglas-fir based on stem analysis data and forest habitat type. Forest Science 30: 943-965. 1984.

MOREIRA, M.; THIERSCH, C.; DE ANDRADE, M.; SCOLFORO, J. Estimativa da relação hipsométrica com modelos não lineares ajustados por métodos bayesianos empíricos. Cerne, 2I(3), 405-4II. 2015.

OLIVEIRA, G.; DE MELLO, J.; ALTOÉ, T.; SCALON, J.; SCOLFORO, J.; PIRES, J. Equações hipsométricas para Eucalyptus spp. não manejado em idade avançada com técnicas de inclusão de covariante. Cerne, 2I (3), 483-492. 20 I5.
OSUMI, S. Applicabilité de la fondion de Richards al'analyse de Croissance de l'arbre. Les colloques INRA I7: 77-86. 1983.

PRODAN, M.; PETERS, R.; COX, F.; REAL, P. Mensura forestal. Serie Investigación y Educación en Desarrollo Sostenible. Instituto Interamericano de Cooperación para la Agricultura (IICA), San José, Costa Rica. 586 pp. 1997.

PUNTIERI, J.; TORRES, C.; GHIRARDI, S. Growth and branching in Nothofagus alpina and Nothofagus obliqua (Nothofagaceae) under different light conditions. Boletin de la sociedad argentina de botanica, 48(2), 277-293. 2013.

PUNTIERI, J.; GHIRARDI, S. Growth-unit structure in trees: effects of branch category and position on Nothofagus nervosa, $\mathrm{N}$. obliqua and their hybrids (Nothofagaceae). Trees, 24(4), 657-665. 2010.

RETSLAFF, F.; FIGUEIREDO FILHO, A.; DIAS, A.; BERNETT, L.; FIGURA, M. Site index curves and hypsometric relationship for Eucalyptus grandis plantations for the Campos Gerais Region, Parana State. Cerne, 2I(2), 219-225. 2015.

RICHARDS, F. A flexible growth function for empirical use. The Journal of Experimental Botany 10(29): 290-300. 1959.

SALAS, C.; GARCIA, O. Modelling height development of mature Nothofagus obliqua. Forest Ecology and Management 229(I-3): I-6. 2006.

SKOVSGAARD, J.; VANCLAY, J. Forest site productivity: a review of the evolution of dendrometric concepts for even- aged stands. Forestry 8I(I): |3-3I. 2008.

SPURR, S.; BARNES, B. Forest Ecology. Third Edn. The Ronald Press Co. New York. 57I pp. 1980.

VANCLAY, J. Modeling Forest Growth and Yield: Applications to Mixed Tropical Forests. Wallingford, CAB International. 312 pp. 1994.

WATT, M.; KIRSCHBAUM, M.; PAUL, T.; TAIT, A.; PEARCE, H.; BROCKERHOFF, E.; MOORE, J.; BULMAN, L.; KRITICOS, $D$. The effect of climate change on New Zealand's planted forests. No, I. 149 pp. 2008.

ZEIDE, B. Analysis of growth equations. Forest Science 39(3): 594-616. 1993. 